\title{
Employee Innovation Behavior in Health Care
}

\author{
Abdul Haeba Ramli* \\ Master of Management \\ Universitas Trisakti \\ Jakarta, Indonesia \\ *abdul.haeba@trisakti.ac.id
}

\begin{abstract}
The objective of this research is to analyze the influence of Humble Leadership towards Employee Innovation Behavior. This research Applies the explanatory type with quantitative approach. The sample that used for this research are 100 respondents of Hospital employee. The collection of data that used in this research is the survey who have to answer the questions that are given by the researcher. The result is Analyzed by descriptive analysis and path analysis. The empirical results indicated resources was humble leadership that has an important role construct that has the most significant and significant influence on employee behavior through innovation core selfevaluation. The research in this study is to examine the influence of humble leadership towards the Employee Innovation Behavior. Positive influence of core self-evaluation on employee innovation behavior. Positive influence humble leadership to core self-evaluation. The conceptual framework variable in this study added the constructs by using Humble leadership as independent variables, where the influence of humble leadership behavior on employee innovation through core self-evaluation is important in the future in the healthcare services.
\end{abstract}

Keywords-humble leadership, innovation behavior, core selfevaluation, employee hospital, healthcare services

\section{INTRODUCTION}

Asean free trade period began in 2015 , including health services, resulting in the issuance of joint regulations on freedom of labor in the health sector to work in all countries included in the membership of ASEAN [1]. This situation must embody the increasingly fierce competition in the industry is the National Hospital [2]. Besides the competition at the national level, hospitals competition in Indonesia also have to face a multitude of patient trust-enabled upper middle of the health services provided by a hospital abroad, especially in Asean which resulted in the release of foreign exchange [3]. This is caused because the company's strategy that is effective in creating a market for products services and also due to the loyalty of patients who have been formed by the emergence of confidence in order to recover if treated in Hospital [4]. Patient confidence grew as Hospital's credibility for pain has been formed [2], while Hospital's credibility form of services provided by the physical facilities provided by the hospital and also by the service provided by the employees who are in direct contact with the patient [5]

Organizations seeking to encourage employees to be innovative behavior in providing services to consumers, will impact on improving operational efficiency in the presentation of its services and improve the efficiency of time to carry out the transaction [6], so that the business environment of the can increase the competitive strategy [7] and raise the performance of the company [8]. Because customers, especially those users, expect a service company to anticipate and meet their needs, so as to encourage companies to provide new services, new quality, or an increase in the service process [9].

In the service industry, an important paradigm for innovation is that customer demand will be able to function as a driving force for innovation [10]. Therefore, business and social environments that support is needed, especially for the implementation of new ideas [11]. The main concern for managers, is how to create an Employee Innovation Behavior among employees. Individuals who are empowered will feel that their talents and aspirations match the value system that encourages them to invest in a positive mental energy [12].

This situation leads to the tendency of employees feel comfortable with the organization that raises employee commitment to the organization [13]. Commitments have been formed, will help organizations to gain optimal performance of employees [14]. Although to encourage employees to improve their performance, a leader must make people feel that they have the ability, capacity, and control to do the job [15]. And one of the proven models of leadership that can positively influence the Employee Innovation Behavior is Humble leadership [12]. Besides being able to influence the employee innovation behavior, the findings of the study [12] also showed that the leaders of the humble or humble leadership was shown to significantly increase the Core Self Evaluation or the level of self-evaluation followers/ employees, which is important and needed by employees to have the ability to identify the conditions where these humble effective leadership for its staff.

This research is interesting for writers because they want to contribute to the lack of research using a construct to connect the leadership of the humble (humble leadership), the level of 
self-evaluation of employees (core self-evaluation), and innovative behavior employee (employee innovation behavior) [12], so there is a gap that needs to be covered through the literature of this research.

\section{LITERATURE REVIEW}

The concept of modesty as "desired personal qualities which is an understanding of ourselves through the consciousness of identity, strength, and personal limitations [16]. Humility as interpersonal characteristics that connote a desire to see themselves accurately; an appreciation of the strengths and contributions of others; and the ability to teach, or openness to new ideas and new feedback [17]. In short, Humble leadership is unique because of its focus on transparency of the leader of their own development process.

Humble leadership is a leadership approach from the bottom to the top which involves listening, observing others and learning by doing [12]. Employees who have the core selfevaluation high will lead to a strong internal motivation has, cognition positive, good skills, have more emotional and a positive attitude, and behave reactively [18]. Innovation is also a result of involvement with co-workers and others to generate and realize ideas for products, services and work processes for new and / or improved [19].

An innovation related to the formulation of new ideas and useful as well as the implementation of the concept. It also includes incremental improvements to products, services, and processes and the adaptation of products and processes from outside the organization [12]. Minimal attention to innovation at the level of individuals or groups, including the effect of working group on innovative behavior of individuals [12]. In particular, employee innovation behavior develops, adopt and implement new ideas for products and methods of work - is considered as an important asset of the company [20].

\section{A. Hypothesis Development Research}

Humble Leadership impact on employee innovation behavior. A leader can show direct influence by directing and evaluating the work of employees to control their access to resources and information [21]. Humble leader can be considered as a form of ambient stimulus and the stimulus is spread widely in organization and recognized by the subordinate [22]. Previous studies have proved that Humble Leadership and significant positive effect on employee innovation behavior [12].

H1: There is a positive impact on employee innovation Humble Leadership behavior.

The positive effect is to increase the confidence and optimism of the employees as a first step for innovative behavior [23]. In addition, Employee innovation behavior relies on information input from customers to employees obtained at the service center of innovation in the information or knowledge, Employee innovation behavior derived from the company's ability to investigate existing problems of external information sources so that the different paradigms can be obtained [24]. Research has shown that core self-evaluation and a significant positive effect on employee innovation behavior [12].

H2: There is a positive impact of core self-evaluation on employee innovation behavior.

Humble leadership have a significant impact on the process and results related to organizational learning and deepening Core self-evaluation [17]. Humility is regarded as the core content of servant leadership and verify a positive relationship between Humble leadership and employees who have the Core Self-Evaluation is high $[25,26]$. A person who has humble leadership, if it can be perceived by subordinates, it will affect relationships, communication and level of trust with the employees and the management [27]. These factors in turn may affect the commitment, engagement, and employee performance [28]. Research conducted previously also been proved that Humble leadership and significant positive effect on self-evaluation core $[12,25,26]$.

H3: There is a positive effect of Humble Leadership of the core self-evaluation.

To improve the recognition of Employee innovation behavior through promotion within the organization, the leaders who have Humble leadership will present early stage, innovative work to more senior managers [29]. Empirical studies found that leaders who have humble leadership, will serve the impact of the growing creativity of employees by means of foster an environment that promotes spirituality of the workplace [30]. Employees with core self-evaluation own high self-concept and psychological resources are more positive; they are willing to continue to learn and challenge themselves to perform services closely linked to innovation Employee behavior [31]. The positive outlook of these employees, will affect other outcomes [32]. The research have proved that Humble leadership and significant positive effect on employee innovation behavior through core self-evaluation [12].

H4: There is a positive impact Humble leadership towards innovation behavior through core employee self-evaluation.

\section{METHODS}

Testing the hypothesis in this study using data analysis method Structural Equation Model (SEM) was run by Amos 6.0 software. Data collection techniques in this study using a questionnaire conducted in a private hospital employee scattered throughout Indonesia as respondents conducted in January and March 2019. From all questionnaires distributed via e-mail, the result of 100 (one hundred) respondents were valid. The number of indicators used in this study were 11 items, so that the number of samples have exceeded the minimum of 55 samples.

The number of respondents more women than men are men amounted to $43(43 \%)$ and 57 women (57\%). Age less than 20 years of age by $1(1 \%)$ and the rest in the 20-25 years age of 10 (10\%), 26-30 year amounted to $18(18 \%), 31-35$ years 10 
(10\%), and over 35 years amounted to $61(61 \%)$. Judging by the latest education that is more senior is 3 people (3\%), and the rest are College as much as 97 respondents $(97 \%)$.

TABLE I. CONFIRMATORY FACTOR ANALYSIS FOR MEASUREMENT MODEL

\begin{tabular}{|l|l|l|}
\hline \multicolumn{1}{|c|}{ Constructs and Indicator } & $\begin{array}{c}\text { Standardize } \\
\text { factor } \\
\text { loadings }\end{array}$ & $\begin{array}{c}\text { Cronbach's } \\
\text { alpha }\end{array}$ \\
\hline Humble Leadership: & .569 & .626 \\
The willingness to see yourself & .673 & \\
accurately people & .653 & \\
Respect for others & & \\
strength & & \\
Teachable & .751 & .783 \\
Core Self Evaluation: & .740 & \\
Pride & .657 & \\
Confidence in the ability of self & \\
emotional stability & .638 & .655 \\
locus of control & .577 & \\
\hline Employee Innovation Behavior: & .655 & \\
Finding problems & .548 & \\
Generate ideas & .627 & \\
Looking for creative support & & \\
Applying innovation plan & & \\
\hline
\end{tabular}

Source: processed data

Based on Table 1 value factor loading for indicator above has a value of factor loading $>0,50$ [33], so that it can be concluded that all indicators are appropriate or capable of defining the constructs of each variables. Reliability construct was measured using indicators the value of Cronbach alpha> 0.60 , it is presented that the answers of respondents to the indicators used in the study to measure all the variables construct reliable and dependable or consistent.

TABLE II. TEST GOODNESS OF FIT MODELS

\begin{tabular}{|c|c|c|c|c|}
\hline $\begin{array}{c}\text { Type } \\
\text { Measurement }\end{array}$ & Measurement & Score & $\begin{array}{l}\text { Receiving } \\
\text { limits that } \\
\text { are } \\
\text { suggested }\end{array}$ & Conclusion \\
\hline \multirow{3}{*}{$\begin{array}{l}\text { Absolute fit } \\
\text { measures }\end{array}$} & Chi-square & $\begin{array}{l}217 \\
964\end{array}$ & $\begin{array}{l}\text { Small } \\
\text { expected }\end{array}$ & $\begin{array}{l}\text { Not } \\
\text { Goodness } \\
\text { of Fit }\end{array}$ \\
\hline & $\begin{array}{l}\text { p-value Chi- } \\
\text { Square }\end{array}$ & 0000 & $\geq 0.05$ & $\begin{array}{l}\text { Not } \\
\text { Goodness } \\
\text { of Fit }\end{array}$ \\
\hline & RMSEA & .096 & $\leq 0.10$ & $\begin{array}{l}\text { Goodness } \\
\text { of Fit }\end{array}$ \\
\hline \multirow{4}{*}{$\begin{array}{l}\text { Incremental fit } \\
\text { measures }\end{array}$} & NFI & .707 & $\begin{array}{l}\geq 0.90, \text { or } \\
\text { close to } 1\end{array}$ & $\begin{array}{l}\text { marginal } \\
\text { Fit }\end{array}$ \\
\hline & TLI & .764 & $\begin{array}{l}\geq 0.90, \text { or } \\
\text { close to } 1\end{array}$ & $\begin{array}{l}\text { marginal } \\
\text { Fit }\end{array}$ \\
\hline & RFI & .607 & $\begin{array}{l}\geq 0.90, \text { or } \\
\text { close to } 1\end{array}$ & $\begin{array}{l}\text { Not } \\
\text { Goodness } \\
\text { of Fit }\end{array}$ \\
\hline & CFI & .824 & $\begin{array}{l}\geq 0.90, \text { or } \\
\text { close to } 1\end{array}$ & $\begin{array}{l}\text { marginal } \\
\text { Fit }\end{array}$ \\
\hline $\begin{array}{l}\text { Parsimonious } \\
\text { fit measure }\end{array}$ & CMIN / DF & 1,912 & $\begin{array}{l}\text { The lower } \\
\text { limit of } 1 \text {, } \\
2,3,4 \text { or } 5\end{array}$ & $\begin{array}{l}\text { Goodness } \\
\text { of Fit }\end{array}$ \\
\hline
\end{tabular}

Based on testing the value of goodness of fit of the table 2 above, it can be concluded that the overall model used, the goodness of fit is CMIN / DF and RMSEA and CFI, TLI, NFI is Marginal Fit, so do the next test [33].

\section{RESULTS AND DISCUSSION}

\section{A. Result}

The results of data processing are carried out to test the hypothesis, as described in Table 3 below:

\section{TABLE III. HYPOTHESIS TEST}

\begin{tabular}{|l|l|l|l|}
\hline \multicolumn{1}{|c|}{ Hypothesis } & Coefficient & P-value & Decision \\
\hline $\begin{array}{l}\text { H1: There is a positive influence } \\
\text { on employee innovation } \\
\text { Humble leadership behavior. }\end{array}$ & 0174 & 0044 & $\begin{array}{l}\text { be } \\
\text { supported }\end{array}$ \\
\hline $\begin{array}{l}\text { H2: There is a positive effect of } \\
\text { Core Self-evaluations on } \\
\text { employee innovation behavior. }\end{array}$ & 0451 & $0: 38$ & $\begin{array}{l}\text { be } \\
\text { supported }\end{array}$ \\
\hline $\begin{array}{l}\text { H3: There is a positive influence } \\
\text { Humble leadership of the Core } \\
\text { Self-evaluations. }\end{array}$ & 0502 & 0000 & $\begin{array}{l}\text { be } \\
\text { supported }\end{array}$ \\
\hline $\begin{array}{l}\text { H4: There is a positive influence } \\
\text { on employee innovation } \\
\text { Humble leadership behavior } \\
\text { through the Core Self- } \\
\text { evaluations. }\end{array}$ & 0216 & 0049 & $\begin{array}{l}\text { be } \\
\text { supported }\end{array}$ \\
\hline
\end{tabular}

\section{B. Discussion}

Tests on the issue of this study show evidence that there is a positive and significant effect of Humble leadership on employee innovation behavior, then other results prove that there is positive but not significant from the Core Selfevaluations on employee innovation behavior, then the next result is a positive influence and significant Humble leadership of the Core self-evaluations, and test results are not directly prove that there is a positive and significant effect of Humble leadership towards innovation behavior through Core Employee self-evaluation.

Based on the results in Table 3 , it can be seen that a stronger relationship shown in the indirect influence between Humble leadership of the Employee Innovation Behavior through mediators Core Self Evaluation compared to the direct relationship between Humble Leadership on Employee Innovation Behavior. And the fourth most powerful this hypothesis is shown by the third hypothesis that look at the effect. Humble leadership of the Core Self-evaluations.

If the results of the above data are shown in Table 3 indicate that the fourth research hypothesis has proved a positive and significant effect, but the second hypothesis proved that although there is positive but not significant from the Core Self-evaluations on employee innovation behavior. 


\section{CONCLUSION}

The conclusion of this study is all hypothesis are supported. Departing from the above conclusion, the results of this study should be used by management to determine the direction of policy on the management of human resources, especially in the field of health services. This study is also expected to provide inputs for the internal stakeholders in improving the Employee Innovation Behavior. Finally, this research is also expected to be a mirror for the management of the vertical relationship between the leader with employees to improve the level of Core Self-evaluations. Limitations and Suggestions. Advice can be given for further research is that for future research in order to further increase support variables that shape innovation employee behavior. Due to this research using only variable Humble leadership, and Core Selfevaluations to be seen the effect. For further research, it should be considering adding another impact for example with variable psychological empowerment [27] and follower engagement [34].

\section{REFERENCES}

[1] H. Wangke, "Peluang Indonesia Dalam Masyarakat Ekonomi Asean 2015,” Info Singk Hub Int., Vol. VI, No. 10, pp. 5-8, 2013.

[2] B. Imran and A.H. Ramli, "Kepuasan pasien, citra rumah sakit dan kepercayaan pasien di Provinsi Sulawesi Barat," In: Seminar Nasional Pakar. p. 2.48.1-2.48.7, 2019.

[3] M.N. Abdi and M. Hidayat, "Analysis of the effect of investment risk factors on pharmaceutical companies listing on the Indonesia Stock Exchange," J Econ., Vol. 4, No. 1, pp. 153-64, 2016

[4] A.H. Ramli and H. Sjahruddin, "Building patient loyalty in healthcare services,” Int Rev Manag Bus Res., Vol. 4, No. 2, pp. 391-401, 2015.

[5] A.H. Ramli, "Pengaruh sistem penyampaian jasa terhadap citra Rumah Sakit swasta Tipe C di Makassar," Media Ris Bisnis Manaj. Vol. 13, No. 2, pp. 147-68, 2013.

[6] A.Y. Obeng and E. Boachie, "The impact of IT-technological innovation on the productivity of a bank's employee," Cogent Bus Manag., Vol. 5 , No. 1, pp. 1-19, 2018

[7] S. Mariam and A.H. Ramli, "Lingkungan bisnis, kapabilitas unik dan strategi bersaing perusahaan distributor ayam di Provinsi DKI Jakarta," In: Seminar Nasional Pakar, p. 2.42.1-2.42.6, 2019.

[8] S. Mariam and A.H. Ramli, "Determinan kinerja perusahaan pada distributor unggas di Provinsi DKI Jakarta," In: Seminar Nasional Cendekiawan, p. 413-7, 2017.

[9] M. Sigala, "Social networks and customer involvement in new service development (NSD):The case of www.mystarbucksidea.com," Int J Contemp Hosp Manag., Vol. 24, No. 7, pp. 966-90, 2012.

[10] A.M. Hjalager, "A review of innovation research in tourism," Tour Manag., Vol. 31, No. 1, pp. 1-12, 2010.

[11] M. Li and C.H.C. Hsu, "Customer participation in services and employee innovative behavior: The mediating role of interpersonal trust," Int J Contemp Hosp Manag., Vol. 30, No. 4, pp. 2112-31, 2018.

[12] F. Zhou and Y.J. Wu, "How humble leadership fosters employee innovation behavior: A two-way perspective on the leader-employee interaction," Leadersh Organ Dev J., Vol. 39, No. 3, pp. 375-87, 2018.

[13] A.H. Ramli, "Person-organization fit dalam rantai distribusi pemasaran (Person-organization fit in the marketing distribution chain)," $\mathrm{J}$ Manaj dan Pemasar Jasa, Vol. 12, No. 1, pp. 77, 2019.

[14] S.S. Puteri and A.H. Ramli, "Determinan kinerja karyawan pada PT Kinden Indonesia di Jakarta,” In: Seminar Nasional Cendekiawan, 2017.
[15] B. Afsar, S. Cheema and Bin Saeed B, "Do nurses display innovative work behavior when their values match with hospitals' values?,” Eur J Innov Manag. Vol. 21, No. 1, pp. 157-71, 2018.

[16] R. Nielsen, J.A. Marrone and H.S. Slay, "A new look at humility: Exploring the humility concept and its role in socialized charismatic leadership," J Leadersh Organ Stud. Vol. 17, No. 1, pp. 33-43, 2010.

[17] B.P. Owens and D.R. Hekman, "Modeling how to grow: An inductive examination of humble leader behaviors, contingencies, and outcomes,' Acad Manag J., Vol. 55, No. 4, pp. 787-818, 2012.

[18] C.H. Chang, D.L. Ferris, R.E. Johnson, C.C. Rosen and J.A. Tan, "Core self-evaluations: A review and evaluation of the literature," J Manage. Vol. 38, No. 1, pp. 81-128, 2012.

[19] X. Yuan, Z. Guo and E. Fang, "An examination of how and when the top management team matters for firm innovativeness: The effects of TMT functional backgrounds," Innov Manag Policy Pract. Vol. 16, No. 3, pp. 323-42, 2014

[20] F. Yuan, "Individual innovation in the workplace: the role of performance and image outcome expectations," [Online]. 2005, from: http://search.proquest.com/docview/304363149?accountid=8401

[21] V. Gupta and S. Singh, "How leaders impact employee creativity: A study of Indian R\&D laboratories," Manag Res Rev. Vol. 36, No. 1, pp 66-88, 2013.

[22] K.N. Walters and D.L. Diab, "Humble leadership: Implications for psychological safety and follower engagement," J Leadersh Stud. Vol. 10, No. 2, pp. 7-18, 2016

[23] Z. Geng, C. Liu, X. Liu and J. Feng, "The effects of emotional labor on frontline employee creativity," Int J Contemp Hosp Manag. Vol. 26, No. 7, pp. 1046-64, 2014.

[24] F. Sørensen and J.F. Jensen, "Value creation and knowledge development in tourism experience encounters," Tour Manag., Vol. 46, pp. 336-46, 2015

[25] C.B. Flynn, J.W. Smither and A.G. Walker, "Exploring the Relationship Between Leaders' Core Self-Evaluations and Subordinates' Perceptions of Servant Leadership: A Field Study,” J Leadersh Organ Stud. Vol. 23, No. 3, pp. 260-71, 2016.

[26] L. Tischler, R. Giambatista, R. McKeage and D. McCormick, "Servan Leadership and its Relationships with Core Self-Evaluation and Job Satisfaction," J Values-Based Leadersh, vol. 9, No. 1, pp. 1-20, 2016.

[27] C.W. Jeung and H.J. Yoon, "Leader humility and psychological empowerment: investigating contingencies," J Manag Psychol., Vol. 31, No. 7, pp. 1122-36, 2016.

[28] Y. Wang, J. Liu and Y. Zhu, "How does humble leadership promote follower creativity? The roles of psychological capital and growth need strength," Leadersh Organ Dev J. Vol. 39, No. 4, pp. 507-21, 2018.

[29] R. Bysted and K.R. Jespersen, "Exploring Managerial Mechanisms that Influence Innovative Work Behaviour: Comparing private and public employees," Public Manag Rev., Vol. 16, No. 2, pp. 217-41, 2014.

[30] W.A. Williams, R.S. Brandon, M. Hayek, S.P. Haden and G. Atinc, "Servant leadership and followership creativity: The influence of workplace spirituality and political skill," Leadersh Organ Dev J., Vol. 38, No. 2, pp. 178-93, 2017.

[31] Y.H. Chiang, C.C. Hsu and K.P. Hung, "Core self-evaluation and workplace creativity,” J Bus Res. Vol. 67, No. 7, pp. 1405-13, 2014.

[32] B.K. Joo and S.J. Jo, "The effects of perceived authentic leadership and core self-evaluations on organizational citizenship behavior: The role of psychological empowerment as a partial mediator," Leadersh Organ Dev J., Vol. 38, No. 3, pp. 463-81, 2017.

[33] J.F. Hair, W.C. Black, B.J. Babin and R.E. Anderson, Multivariate Data Analysis. 7th editio. New Jersey: Pearson Prentice Hall, 2010.

[34] O. Demirtas, S.T. Hannah, K. Gok, A. Arslan and N. Capar, "The Moderated Influence of Ethical Leadership, Via Meaningful Work, on Followers' Engagement, Organizational Identification, and Envy," J Bus Ethics., Vol. 145, No. 1, No. 183-99, 2017. 